CLINICAL STUDY

\title{
Serum paraoxonase and arylesterase activities in metabolic syndrome in Zahedan, southeast Iran
}

\author{
Mohammad Hashemi, Dor Mohammad Kordi-Tamandani ${ }^{1}$, Nooshin Sharifi ${ }^{1}$, Abdolkarim Moazeni-Roodi ${ }^{2}$, \\ Mahmoud-Ali Kaykhaei ${ }^{3}$, Behzad Narouie ${ }^{3}$ and Adam Torkmanzehi ${ }^{1}$ \\ Department of Clinical Biochemistry, School of Medicine, Zahedan University of Medical Sciences, Zahedan 98167-43175, Iran, ${ }^{1}$ Department of Biology, \\ Faculty of Sciences, University of Sistan and Baluchestan, Zahedan 98155-987, Iran and ${ }^{2}$ Research Center for Infectious Diseases and Tropical Medicine \\ and ${ }^{3}$ Department of Internal Medicine, School of Medicine, Zahedan University of Medical Sciences, Zahedan 98167-43175, Iran \\ (Correspondence should be addressed to M Hashemi; Email: mhd.hashemi@gmail.com)
}

\begin{abstract}
Objective: Paraoxonase (PON) is associated with high-density lipoprotein and protects serum lipid from oxidation. The aim of this study was to determine serum PON, arylesterase (ARE) activities, and total antioxidant capacity (TAC) in metabolic syndrome (MES).

Methods: This case-control study was performed on 106 patients with MES and 231 healthy subjects. Serum PON and ARE activities were determined spectrophotometrically. TAC was determined using ferric reducing ability of plasma assay.

Results: The results showed that serum PON activity was significantly lower in patients with MES $(69.62 \pm 59.86 \mathrm{IU} / \mathrm{l})$ than healthy subjects $(91.64 \pm 77.45 \mathrm{IU} / \mathrm{l})(P<0.05)$. The serum ARE activity in MES and normal subjects were $45.23 \pm 23.24$ and $65.69 \pm 31.10 \mathrm{kU} / \mathrm{l}$ respectively. The ARE activity was significantly lower in patients with MES than normal subjects $(P<0.0001)$. No significant differences were observed between MES and normal subjects regarding TAC.

Conclusion: The lower PON and ARE activities in MES may be considered an independent risk factor for cardiovascular disease, which remains to be cleared.
\end{abstract}

European Journal of Endocrinology $164219-222$

\section{Introduction}

Metabolic syndrome (MES), a collection of cardiovascular risk factors including central obesity, hypertension, hyperglycemia, glucose intolerance, and dyslipidemia, is associated with an increased risk of cardiovascular disease and diabetes (1). Human serum paraoxonase 1 (PON1) is $\sim 43-45 \mathrm{kDa}$ glycoprotein, synthesized mainly by the liver, which circulates in serum in association with high-density lipoprotein (HDL) and protects low-density lipoprotein (LDL) from oxidation by the hydrolysis of biologically active lipoperoxides (2). The activity of this enzyme is measured using paraoxon or is estimated from the activity of arylesterase (ARE) using phenyl acetate. It has been reported that ARE activity is not affected by the polymorphisms of PON1 $(3,4)$.

Serum PON1 activity was found to be reduced in a number of pathological conditions including coronary artery disease (5), hypercholesterolemia (6), type 2 diabetes $(6,7)$, polycystic ovary syndrome $(8)$, and renal failure (9). PON1 is recognized as an antioxidant enzyme because it hydrolyzes lipid peroxides in oxidized lipoproteins.
To the best of our knowledge, information regarding PON and ARE activities in MES is limited. The aim of this study was to find out the levels of PON and ARE activities in MES.

\section{Materials and methods}

This case-control study was performed on 106 individual with MES and 231 normal subjects. The demographic and biochemical characteristic of the groups are shown in Table 1.

The study was approved by the local ethical committee of Zahedan University of Medical Sciences and written informed consent was obtained from all subjects. The MES was determined as the presence of three or more of five components according to the national cholesterol education program (NCEP) ATP III (Table 2) (1).

Fasting blood glucose (FBG) and lipid profile (TG, total cholesterol, LDL-C, and HDL-C concentrations) were measured by automated chemistry analyzer using commercial available kits (Table 1). 
Table 1 Biochemical parameters in metabolic syndrome (MES) and normal subjects.

\begin{tabular}{lccc}
\hline Parameters & MES & $\begin{array}{c}\text { Normal } \\
\text { subjects }\end{array}$ & $\boldsymbol{P}$ value \\
\hline FBG $(\mathrm{mg} / \mathrm{dl})$ & $118.50 \pm 58.71$ & $85.42 \pm 12.33$ & $<0.0001$ \\
TG $(\mathrm{mg} / \mathrm{dl})$ & $222.89 \pm 190.66$ & $113.33 \pm 48.31$ & $<0.0001$ \\
$\begin{array}{c}\text { Total cholesterol } \\
(\mathrm{mg} / \mathrm{dl})\end{array}$ & $212.71 \pm 48.80$ & $173.71 \pm 40.25$ & $<0.0001$ \\
HDL-C (mg/dl) & $41.58 \pm 8.00$ & $45.14 \pm 6.89$ & $<0.0001$ \\
LDL-C (mg/dl) & $125.9 \pm 45.17$ & $102.73 \pm 34.23$ & $<0.0001$ \\
Height (cm) & $160.71 \pm 9.70$ & $163.46 \pm 10.17$ & 0.02 \\
Weight $(\mathrm{kg})$ & $75.39 \pm 14.02$ & $63.72 \pm 13.03$ & $<0.0001$ \\
BMI (kg/m $)$ & $29.15 \pm 4.68$ & $23.83 \pm 4.79$ & $<0.0001$ \\
Waist circumference & $99.32 \pm 12.41$ & $82.39 \pm 15.77$ & $<0.0001$ \\
$\quad(\mathrm{~cm})$ & & & \\
SBP $(\mathrm{mmHg})$ & $125.89 \pm 19.78$ & $113.81 \pm 13.75$ & $<0.0001$ \\
DBP $(\mathrm{mmHg})$ & $80.84 \pm 12.25$ & $73.85 \pm 10.63$ & $<0.0001$ \\
\hline
\end{tabular}

PON activity assays were performed in the absence (basal activity) and presence of $1 \mathrm{M} \mathrm{NaCl}$ (salt-stimulated activity) using paraoxone (diethyl-pnitrophenyl phosphate) as a substrate as described previously (10).

Phenylacetate was used as a substrate to determine the ARE activity. The rate of phenol produced was continuously monitored at $270 \mathrm{~nm}$ at $37^{\circ} \mathrm{C}$. ARE activity was determined using molar extinction coefficient of phenol (1310/M per $\mathrm{cm})$ and expressed as kU/l serum (10).

Serum total antioxidant capacity (TAC) was determined by measuring their ability to reduce $\mathrm{Fe}^{3+}$ to $\mathrm{Fe}^{2+}$, which is known as ferric reducing ability of plasma (FRAP) assay as described previously (11).

Statistical analysis was performed by commercial software (SPSS for Windows, V17) using independent sample $t$-test and the Pearson correlation coefficient test. A $P$ value $<0.05$ was considered statistically significant.

\section{Results}

The study consisted of 106 MES (34 males and 72 females; age 43.54 \pm 14.07 ) and 231 normal subjects (97 males and 134 females; age $35.64 \pm 13.27$ ). The levels of PON1 activity in MES and healthy subjects

Table 2 Criteria for diagnosis of the metabolic syndrome according to the national cholesterol education program (NCEP) ATP III.

\begin{tabular}{ll}
\hline Criterion & NCEP ATP III \\
\hline Waist $(\mathrm{cm})$ & \\
Male & $\geq 102$ \\
Female & $\geq 88$ \\
HDL $(\mathrm{mg} / \mathrm{dl})$ & $<40$ \\
Male & $<50$ \\
Female & $\geq 150$ \\
Triglyceride $(\mathrm{mg} / \mathrm{dl})$ & $\geq 100$ \\
Fasting glucose $(\mathrm{mg} / \mathrm{dl})$ & $\geq 130 / 85$ \\
Blood pressure $(\mathrm{mmHg})$ & \\
\hline
\end{tabular}

${ }^{\mathrm{a}}$ Three of five required.
(Table 3) were $69.62 \pm 59.86$ and $91.64 \pm 77.45 \mathrm{IU} / \mathrm{l}$ respectively. The activity of PON in MES was significantly lower than normal subjects $(P=0.01)$. In addition, salt-stimulated PON activity was significantly lower in MES $(136.23 \pm 111.80 \mathrm{IU} / \mathrm{l})$ than normal subjects $(192.24 \pm 162.68 \mathrm{IU} / \mathrm{l})(P=0.02)$.

The serum ARE activity in MES and normal subjects were $45.23 \pm 23.24$ and $65.69 \pm 31.10 \mathrm{kU} / \mathrm{l}$ respectively (Table 3 ).

In males, there were no significant differences in the activities of PON1 between MES (64.57 $\pm 58.24 \mathrm{U} / \mathrm{l})$ and normal subjects $(90.01 \pm 84.17 \mathrm{U} / \mathrm{l})(P=0.106)$. While a significant difference was found regarding ARE activity in MES $(64.68 \pm 35.08 \mathrm{kU} / \mathrm{l})$ and normal subjects $(40.97 \pm 16.23 \mathrm{kU} / \mathrm{l})(P<0.001)$.

In females, the activity of PON was significantly lower in the MES $(72.01 \pm 60.87 \mathrm{U} / \mathrm{l})$ than in the controls $(92.82 \pm 72.49 \mathrm{U} / \mathrm{l})(P=0.039)$. We also found that ARE activity was significantly lower $(P<0.001)$ in female cases $(47.25 \pm 25.75 \mathrm{kU} / \mathrm{l})$ than in normal subjects $(62.80 \pm 27.6 \mathrm{kU} / \mathrm{l})$.

No significant correlation was observed between age and PON or ARE activities $(P>0.05)$. A significant difference was observed among MES and normal subjects regarding the ARE activity $(P<0.0001)$. No significant difference was observed among MES and normal subjects for TAC. In MES and normal subjects, PON activity was positively correlated with ARE activity $(r=0.368, P<0.0001 ; r=0.594, P<0.0001)$. While a positive correlation was observed between PON and HDL-C in normal subjects $(r=0.168, P=0.01)$, the correlation between MES and HDL-C was not significant $(r=0.122, P=0.21)$. Furthermore, there were no correlations between MES and normal subjects regarding PON and cholesterol, LDL-C, triglyceride, TAC, and body mass index (BMI) $(P>0.05)$.

\section{Discussion}

In this study, we found that PON and ARE activities were significantly lower in MES when compared with normal subjects. The formation of free radicals is a normal outcome of a variety of essential biochemical reactions and can occur at elevated rates under pathophysiological circumstances $(12,13)$. The physiological role of antioxidants is to prevent damage to

Table 3 The levels of paraoxonase (PON), salt-stimulated PON, arylesterase activities, and total antioxidant capacity (TAC) in metabolic syndrome (MES) and healthy subjects.

\begin{tabular}{lccc}
\hline & MES & $\begin{array}{c}\text { Normal } \\
\text { subjects }\end{array}$ & $\boldsymbol{P}$ value \\
\hline PON1 activity $(\mathrm{IU} / \mathrm{l})$ & $69.62 \pm 59.86$ & $91.64 \pm 77.45$ & 0.01 \\
Salt-stimulated & $136.23 \pm 111.80$ & $192.24 \pm 162.68$ & 0.02 \\
PON $(\mathrm{IU} / \mathrm{l})$ & & & \\
ARE $(\mathrm{kU} / \mathrm{l})$ & $45.23 \pm 23.24$ & $65.69 \pm 31.10$ & $<0.0001$ \\
TAC $(\mu \mathrm{mol} / \mathrm{l})$ & $972.46 \pm 374.13$ & $966.97 \pm 380.60$ & 0.912 \\
\hline
\end{tabular}


cellular components arising as a consequence of chemical reactions involving free radicals. PON1 is a specific antioxidative enzyme with both PON and ARE activities. There is little information regarding the levels of PON and ARE in MES. Senti et al. (14) had found that the serum PON1 activity was significantly lower in MES than in normal subjects. Our results are in agreement with this finding. Tabur et al. (15) had found that the levels of PON and ARE activities were not significantly different among nondiabetic MES, non-MES obese patients, and healthy subjects, while total antioxidant status was low in both the MES and obese groups compared to controls.

A variety of PON1 gene polymorphisms have been recognized $(16,17)$. It has been well documented that the two common coding region polymorphisms of the gene PON1 (L55M and Q192R) lead to changes of both the level and activity of the enzyme (18, 19). Moreover, it has been found that promoter polymorphism of PON1, especially $-107 \mathrm{~T} / \mathrm{C}$, affects the PON1 expression and serum concentration (20). On the other hand, acquired factors such as diseases, diet, and lifestyle can also affect the PON1 activity. It has been proposed that consumption of red wine or flavonoidcontaining drinks (21) as well as moderate alcohol intake (22) increases serum PON1 activity. The exact mechanisms affecting low PON1 and ARE activities in MES are yet to be clear.

It is well known that in the general population, MES is associated with increased cardiovascular morbidity and mortality $(23,24)$ and high prevalence of type 2 diabetes mellitus (25). Human PON1, an HDL-associated enzyme, is capable of preventing LDL oxidation. According to this and previous results (14), reduced PON and ARE activities in MES might be an independent risk factor for cardiovascular disease in these patients. However, more studies in diverse populations are needed for clear confirmation.

\section{Declaration of interest}

The authors declare that there is no conflict of interest that could be perceived as prejudicing the impartiality of the research reported.

\section{Funding}

This project was supported by a research grant from Zahedan University of Medical Sciences.

\section{Acknowledgements}

The authors would like to thank the patients and healthy subjects who willingly participated in the study.

\section{References}

1 Executive Summary of The Third Report of The National Cholesterol Education Program (NCEP) Expert Panel on Detection,
Evaluation, And Treatment of High Blood Cholesterol In Adults (Adult Treatment Panel III). Journal of the American Medical Association 2001285 2486-2497. (doi:10.1001/jama.285.19.2486)

2 Mackness MI, Arrol S \& Durrington PN. Paraoxonase prevents accumulation of lipoperoxides in low-density lipoprotein. FEBS Letters 1991286 152-154. (doi:10.1016/0014-5793(91)80962-3)

3 Phuntuwate W, Suthisisang C, Koanantakul B, Mackness MI \& Mackness B. Paraoxonase 1 status in the Thai population. Journal of Human Genetics $2005 \mathbf{5 0}$ 293-300. (doi:10.1007/ s10038-005-0255-7)

4 Lopez-Flores I, Lacasana M, Blanco-Munoz J. Aguilar-Garduno C, Sanchez-Villegas P, Perez-Mendez OA \& Gamboa-Avila R. Relationship between human paraoxonase-1 activity and PON1 polymorphisms in Mexican workers exposed to organophosphate pesticides. Toxicology Letters 2009188 84-90. (doi:10.1016/j. toxlet.2009.03.010)

5 Jayakumari N \& Thejaseebai G. High prevalence of low serum paraoxonase-1 in subjects with coronary artery disease. Journal of Clinical Biochemistry and Nutrition 200945 278-284. (doi:10. 3164/jcbn.08-255)

6 Mackness MI, Harty D, Bhatnagar D, Winocour PH, Arrol S, Ishola $M$ \& Durrington PN. Serum paraoxonase activity in familial hypercholesterolaemia and insulin-dependent diabetes mellitus. Atherosclerosis 199186 193-199. (doi:10.1016/00219150(91)90215-0)

7 Abbott CA, Mackness MI, Kumar S, Boulton AJ \& Durrington PN. Serum paraoxonase activity, concentration, and phenotype distribution in diabetes mellitus and its relationship to serum lipids and lipoproteins. Arteriosclerosis, Thrombosis, and Vascular Biology 199515 1812-1818.

8 Mohamadin AM, Habib FA \& Elahi TF. Serum paraoxonase 1 activity and oxidant/antioxidant status in Saudi women with polycystic ovary syndrome. Pathophysiology 201017 189-196. (doi:10.1016/j.pathophys.2009.11.004)

9 Varga E, Seres I, Harangi M, Sztanek F, Asztalos L, Locsey L, Borbas B, Szegedi J, Karpati I \& Paragh G. Serum cystatin C is a determinant of paraoxonase activity in hemodialyzed and renal transplanted patients. Disease Markers 200926 141-148. (doi:10. 3233/DMA-2009-0624)

10 Naderi M, Hashemi M, Komijani-Bozchaloei F, Moazeni-Roodi AK \& Momenimoghaddam MA. Paraoxonase and arylesterase activities in patients with pulmonary tuberculosis. Pathophysiology (accepted for publication).

11 Hashemi M, Mehrabifar H, Daliri M \& Ghavami S. Adenosine deaminase activity, trypsin inhibitory capacity and total antioxidant capacity in psoriasis. Journal of the European Academy of Dermatology and Venereology 201024 329-334. (doi:10.1111/j. 1468-3083.2009.03416.x)

12 Young IS \& Woodside JV. Antioxidants in health and disease. Journal of Clinical Pathology 200154 176-186. (doi:10.1136/jcp. 54.3.176)

13 Knight JA. Free radicals: their history and current status in aging and disease. Annals of Clinical and Laboratory Science 1998 28 331-346.

14 Senti M, Tomas M, Fito M, Weinbrenner T, Covas MI, Sala J, Masia R \& Marrugat J. Antioxidant paraoxonase 1 activity in the metabolic syndrome. Journal of Clinical Endocrinology and Metabolism 200388 5422-5426. (doi:10.1210/jc.2003-030648)

15 Tabur S, Torun AN, Sabuncu T, Turan MN, Celik H, Ocak AR \& Aksoy N. Non-diabetic metabolic syndrome and obesity do not affect serum paraoxonase and arylesterase activities but do affect oxidative stress and inflammation. European Journal of Endocrinology 2010162 535-541. (doi:10.1530/EJE-09-0732)

16 Hashemi M, Moazeni-Roodi AK, Fazaeli A, Sandoughi M, Taheri M, Bardestani GR, Zakeri Z, Kordi-Tamandani DM \& Ghavami S. The L55M polymorphism of paraoxonase-1 is a risk factor for rheumatoid arthritis. Genetics and Molecular Research 20109 1735-1741. (doi:10.4238/vol9-3gmr893)

17 Hashemi M, Moazeni-Roodi AK, Fazaeli A, Sandoughi M, Bardestani GR, Kordi-Tamandani DM \& Ghavami S. Lack of 
association between paraoxonase-1 Q192R polymorphism and rheumatoid arthritis in southeast Iran. Genetics and Molecular Research 20109 333-339. (doi:10.4238/vol9-1gmr728)

18 Aviram M, Hardak E, Vaya J, Mahmood S, Milo S, Hoffman A, Billicke S, Draganov D \& Rosenblat M. Human serum paraoxonases (PON1) Q and R selectively decrease lipid peroxides in human coronary and carotid atherosclerotic lesions: PON1 esterase and peroxidase-like activities. Circulation $2000 \mathbf{1 0 1}$ 2510-2517.

19 Garin MC, James RW, Dussoix P, Blanche H, Passa P, Froguel P \& Ruiz J. Paraoxonase polymorphism Met-Leu54 is associated with modified serum concentrations of the enzyme. A possible link between the paraoxonase gene and increased risk of cardiovascular disease in diabetes. Journal of Clinical Investigation 1997 99 62-66. (doi:10.1172/JCI119134)

20 Leviev I \& James RW. Promoter polymorphisms of human paraoxonase PON1 gene and serum paraoxonase activities and concentrations. Arteriosclerosis, Thrombosis, and Vascular Biology $200020516-521$.

21 Aviram M, Dornfeld L, Rosenblat M, Volkova N, Kaplan M, Coleman R, Hayek T, Presser D \& Fuhrman B. Pomegranate juice consumption reduces oxidative stress, atherogenic modifications to LDL, and platelet aggregation: studies in humans and in atherosclerotic apolipoprotein E-deficient mice. American Journal of Clinical Nutrition 200071 1062-1076.
22 van der Gaag MS, van Tol A, Scheek LM, James RW, Urgert R, Schaafsma G \& Hendriks HF. Daily moderate alcohol consumption increases serum paraoxonase activity; a diet-controlled, randomised intervention study in middle-aged men. Atherosclerosis 1999 147 405-410. (doi:10.1016/S0021-9150(99)00243-9)

23 McNeill AM, Rosamond WD, Girman CJ, Golden SH, Schmidt MI, East HE, Ballantyne CM \& Heiss G. The metabolic syndrome and 11-year risk of incident cardiovascular disease in the atherosclerosis risk in communities study. Diabetes Care 200528 385-390. (doi:10.2337/diacare.28.2.385)

24 Wang J, Ruotsalainen S, Moilanen L, Lepisto P, Laakso M \& Kuusisto J. The metabolic syndrome predicts cardiovascular mortality: a 13-year follow-up study in elderly non-diabetic Finns. European Heart Journal 200728 857-864. (doi:10.1093/ eurheartj/ehl524)

25 Sattar N, Gaw A, Scherbakova O, Ford I, O'Reilly DS, Haffner SM, Isles C, Macfarlane PW, Packard CJ, Cobbe SM \& Shepherd J. Metabolic syndrome with and without C-reactive protein as a predictor of coronary heart disease and diabetes in the West of Scotland Coronary Prevention Study. Circulation 2003108 414-419. (doi:10.1161/01.CIR.0000080897.52664.94)

Received 19 October 2010

Accepted 8 November 2010 